DOI: https://doi.org/10.31392/NZ-npu-144.2019.13

УДК: 37.013.43:784.1

Кулага T. 0.

\title{
НАУКОВО-МЕТОДИЧНА РЕФЛЕКСІЯ КЛАСИЧНОЇ ТА СУЧАСНОЇ ВОКАЛЬНИХ ТЕХНІК В КОНТЕКСТІ ПРОБЛЕМИ КУЛЬТУРОВІДПОВІНОСТІ ВОКАЛЬНОЇ ПЕДАГОГІКИ
}

\begin{abstract}
У статті підкреслено загальну тенденцію сучасного некласичного співу, яка відбивається у поверненні до природних можсливостей людського голосу. Надано систематизовану порівняльну характеристику основних рис класичної та сучасної вокальних технік з точки зору звуковидобування; типових акустичних характеристик голосу; техніки; музикальності та інтерпретаиії. Приведено порівняння деяких позичій, які доиільно враховувати в прочесі педагогічної взаємодії зі співакамипідлітками по оволодінню вокальною технікою в сучасних стилях. Визначено відмінності між сучасною некласичною та традиційною західно-європейською вокальними техніками з позииій принципу культуровідповідності, а саме: розширення меж акустичних характеристик голосу; більш чітковизначена природність фізіологічних прочесів, які супроводжують некласичний спів; інтуітивність, неофіиійність та неформальність виконавських дій сучасного естрадного вокаліста; опора на загальнолюдські та різноманітні етнічні традичї̈; індивідуальний творчий підхід до інтерпретаџї та подання сучасного вокального твору. Окреслено протилежності мію класичною та сучасної вокальною техніками, такі, як постава, повітряний тиск, положення гортані та язику, вокальне виробництво, домінантні м'язи, звукова проекція, вимова звуків. Надано посилання на інформацію відносно інтонаційних та метроритмічних особливостей музичної мови сучасного естрадного вокалу. Наголомено на необхідності переосмислення вокальної педагогіки у відповідності до результатів сучасних досліджень закордонних науковців та врахування отриманих результатів в прочесі роботи з естрадними вокалістами мистецьких икіл.
\end{abstract}

Ключові слова: культуровідповідність, ресемантизаџія, вокальна техніка, естрадний вокал, некласична вокальна педагогіка, мистеиька школа.

В музиці “легкого жанру", до якого відноситься естрадне вокальне мистецтво, особливо останнім часом, розширюється діапазон образних, жанрових та інших можливостей, а художники отримують "виключне право на експеримент” [2, с. 38], що допускає безліч індивідуальних рішень та сприяє появі "змішаного стилю”, виникненню нових умов існування художнього твору і, навіть, зміні сутності самої творчості [4, с. 144-160].

Зміна мистецької парадигми детермінує появу і нової вокальної техніки, яка, згідно О. Бойко, формується під іншокультурними музичними впливами "на власному національному ґрунті" [1, с. 176]. Основною її тенденцією $€$ повернення до “старих" природних можливостей людського голосу, які багато в чому, а іноді і кардинально, відрізняються від академічної західно-європейської співочої традиції. Але практика показує, що у вітчизняних мистецьких школах викладання естрадного вокалу ведуть здебільшого викладачі академічної спрямованості, які орієнтовані на звичний для них сформований канон, який не відповідає в повному обсязі вищезазначеній тенденції, що і становить проблему статті, яку можна сформулювати як відсутність систематизованого знання відносно основних характерних рис сучасної некласичної вокальної 
техніки, що негативно впливає на дотримання принципу культуровідповідності вокальної педагогіки.

В Україні теорія та методологія естрадної вокальної освіти тільки починає формуватися, але вже існують певні достатньо цікаві дослідження з питань естрадно-джазової стилістики (М. Барановська, Л. Бурміцька, О. Павленко, В. Павліковський), особливостей інтонування (Т.Рябуха), викладання естрадного вокалу (Е. Гавацко, Н. Дрожжина, Л. Красовська, Ю. Осетров, Г. Постевка, Т. Ткаченко), фрормування культури виконання (Л. Каменецька, Г. Цзінхен, А. Шевченко) тощо. Не менш цікавими є і дослідження російських (Т. Будницька, 3. Гарина, В. Коробка, А. Мохонько, А. Поляков, О. Пивницька, Е. Рибакова, П. Свиридов, І. Стулов, Л. Сьоміна тощо) та загальновідомих закордонних (К. Лінклейтер, С. Ріггс, К. Седолін) науковців з зазначеної проблематики. Але, слід зазначити, що в них:

- окреслюються лише окремі питання сучасного естрадного вокального виконавства;

- застосовуються дослідження голосової функції, проведені ще у другій половині XX століття;

- проблематика викладання естрадного вокалу розглядається здебільшого з академічних позицій;

- не використовується досвід закордонних дослідників останніх років;

- не достатньо враховуються тенденції сучасної світової музичної культури.

В процесі дослідження було знайдено певну кількість досліджень закордоних науковців, таких, як Т.Бон (Т. Bourne), М. Кастелєнго (M. Castellengo), Б. Чібе (B. Chuberre), М. Ганіа (M. Garnier), Н. Генрих (N. Henrich), Д. Кені (D. Kenny), C. Ламеш (S. Lamesch), M. Морено (M. Moreno), Б. Рубу (B. Roubeau), P. Саталоффр (R. Sataloff), P. Експерт (R. Expert) тощо, які, в доповнення до вже існуючих досліджень, дають можливість більш розгорнуто окреслити основні особливості сучасної некласичної вокальної техніки.

Мета статті полягає у "ресемантизації", як - повторному переосмисленні культурних знаків вокального мистецтва відповідно до сучасного рівня розвитку вокальної культури [5, с. 204] шляхом порівняння і систематизації результатів знайдених досліджень $з$ питань відмінностей і ідентичностей класичної та сучасної вокальної техніки 3 позицій принципу культуровідповідності.

Сучасний вокал у вітчизняній педагогіці розглядається тільки протягом останніх 15-20 років на відміну від США, де з 1970-х років попереднього століття в коледжах та університетах почали пропонувати навчання співу МT (музичний театр), який містить всі характерні риси сучасного вокалу і охоплює усі жанри некласичної вокальної музики.

В американській музичній педагогіці некласична вокальна техніка має назву contemporary vocal technique (CVT), в перекладі на українську - сучасна вокальна техніка (CBT). Цей термін $є$ універсальним і буде використовуватись для позначення сучасної естрадної вокальної техніки. 
Стосовно звуковидобування слід звернути увагу на дослідження Н. Генріх зі співавторами, в якому вони на основі результатів електроглоттографії визначають різницю між зміною конфігурації гортані (гортанного механізму) та регулюванням голосового тракту (регістрового резонансу) та пропонують наступну термінологію чотирьох гортанних механізмів, які відтворюються в певних регістрах, а саме: М0 - штробас (англ. - strowbass або vocal fry), M1 грудний регістр у жінок та чоловіків, М2 - головний у жінок та фальцетний у чоловіків та М3 - свистковий [8, с. 457].

В наступній таблиці пропонуються відмінності типових акустичних характеристик СВТ та класичної вокальної техніки (оперного співу) (скорочено - КВТ), які визначили члени Американської академіі вокальних педагогів (ААВП) (англ. - American Academy of Teachers of Singing, скорочено - AATS) на основі спектрального аналізу співу I. Ме

Таблиця 1

Відмінні риси КВТ та СВТ (за иленами ААВП) [6, с. 8-9]

\begin{tabular}{|c|c|c|c|}
\hline 量 & $\begin{array}{c}\text { Типові } \\
\text { акустичні } \\
\text { характеристики } \\
\text { співу }\end{array}$ & $\begin{array}{c}\text { КВТ } \\
\text { (Оперний спів) }\end{array}$ & CBT \\
\hline 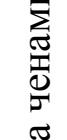 & $\begin{array}{l}\text { акустична } \\
\text { енергія }\end{array}$ & $\begin{array}{l}\text { частотний діапазон, рідко } \\
\text { виходить за межі } 5 \text { кГц }\end{array}$ & $\begin{array}{l}\text { значна амплітуда гармонік на } \\
\text { дуже високих частотах (до } \\
10 \text { кГц) }\end{array}$ \\
\hline 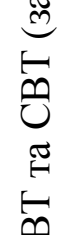 & обертони & $\begin{array}{l}\text { обертони гармонічні, звук, не } \\
\text { забарвлений шумом або } \\
\text { навмисною шорсткістю }\end{array}$ & $\begin{array}{l}\text { між гармоніками часто } \\
\text { помітні інші гармонійні } \\
\text { частоти, що свідчать про } \\
\text { шум або шорсткість, яку } \\
\text { навмисно додають до тону }\end{array}$ \\
\hline 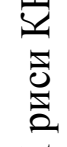 & формантні зони & $\begin{array}{l}\text { помітні через зміну амплітуди } \\
\text { гармонік, постійна амплітуда } \\
\text { гармонік у діапазоні 2,5-3,5 кГц }\end{array}$ & відносно нечіткі \\
\hline 离 & вібрато & активне, незмінне & $\begin{array}{l}\text { змінне, помірне, } \\
\text { використовується, } \\
\text { насамперед, як додатковий } \\
\text { засіб виразності }\end{array}$ \\
\hline
\end{tabular}

Відмінності КВТ та СВТ з позицій техніки, музикальності та інтерпретації пропонує К. Чандлер. 
Відмінні риси КВТ та СВТ (за К. Чандлер) [7]

\begin{tabular}{|c|c|c|c|}
\hline \multirow{21}{*}{ 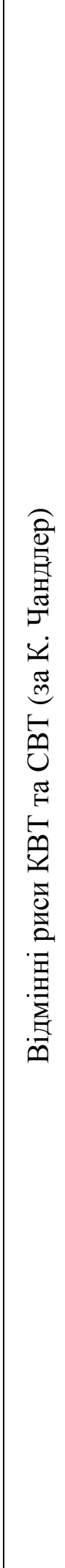 } & $\begin{array}{l}\text { Елементи } \\
\text { вокальної } \\
\text { техніки }\end{array}$ & KBT & CBT \\
\hline & Постава & статична / драматична дія & динамічна / рух в такт \\
\hline & $\begin{array}{l}\text { Вид } \\
\text { голосоведення }\end{array}$ & довгі, легато фрази & коротші (розмовні) фрази \\
\hline & Атака & $\begin{array}{l}\text { одночасна, врівноважена, } \\
\text { узгоджена }\end{array}$ & $\begin{array}{l}\text { придихальна, “жолобна”, } \\
\text { глотальна, “плакальна”” }\end{array}$ \\
\hline & $\begin{array}{l}\text { Положення } \\
\text { гортані }\end{array}$ & нейтральне / занижене & нейтральне / підняте \\
\hline & Співочий тон & $\begin{array}{l}\text { чистий, поставлений, } \\
\text { прикритий тон, (жінки) } \\
\text { використовують “головний” } \\
\text { звук, “ридальну” / “плакальну” } \\
\text { якість }\end{array}$ & $\begin{array}{l}\text { “натуральний” тон, } \\
\text { “грудний” звук (для обох } \\
\text { полів), “мікс" та “белт”, іноді } \\
\text { “twang” або скрипуча якість }\end{array}$ \\
\hline & Дикція & всі приголосні вимовлені & $\begin{array}{l}\text { початкові приголосні } \\
\text { підкреслені, а кінцеві - } \\
\text { приховані }\end{array}$ \\
\hline & Вимова тексту & нормативна & сленг або просторіччя \\
\hline & Ритм & несинкопований, рубато & $\begin{array}{l}\text { синкопований, характерний } \\
\text { для "groove" }\end{array}$ \\
\hline & Вібрато & важке & легке \\
\hline & Інтонування & $\begin{array}{l}\text { використовується традиційний } \\
\text { діатонічний / хроматичний лад }\end{array}$ & $\begin{array}{l}\text { використовується } \\
\text { пентатоніка, гексатонічний, } \\
\text { блюзовий та модальний лади }\end{array}$ \\
\hline & Багатоголосся & $\begin{array}{l}\text { партії з партитури, конкретні } \\
\text { гармонічні правила }\end{array}$ & $\begin{array}{l}\text { інтуітивні партії, тобто “на } \\
\text { слух", тризвуки, акорди з } \\
\text { додатковими ступенями }\end{array}$ \\
\hline & Діапазон & італійські голосові класифікації & $\begin{array}{l}\text { загальні чоловічі та жіночі } \\
\text { діапазони }\end{array}$ \\
\hline & Прикраси & $\begin{array}{l}\text { діатонічна / хроматична } \\
\text { колоратура }\end{array}$ & $\begin{array}{l}\text { пентатонічні / гексатонічні } \\
\text { мелізми }\end{array}$ \\
\hline & $\begin{array}{l}\text { Теоретичні } \\
\text { знання }\end{array}$ & класична теорія & популярна теорія музики \\
\hline & Імпровізація & каденції в авангард-музиці & ad libitum, “ріфи”, “розспіви” \\
\hline & Вокальні ефекти & $\begin{array}{l}\text { в основному зустрічається в } \\
\text { розширених вокальних техніках } \\
\text { (авангард) }\end{array}$ & $\begin{array}{l}\text { може бути використано } \\
\text { вокальне спотворення, } \\
\text { гарчання, бурчання, стогони, } \\
\text { придихальні закінчення тощо }\end{array}$ \\
\hline & Візуалізація & Офіційний одяг & $\begin{array}{l}\text { неформальне шикарне } \\
\text { повсякденне плаття }\end{array}$ \\
\hline & Місце виконання & офіційні вистави & неформальні виступи \\
\hline & Посилення & без підсилення & $\begin{array}{l}\text { виступи завжди посилюються } \\
\text { мікрофоном }\end{array}$ \\
\hline & $\begin{array}{l}\text { Питання } \\
\text { голосового } \\
\text { здоров'я }\end{array}$ & $\begin{array}{l}\text { конкуренція з живим } \\
\text { супроводом оркестру. Гучні, } \\
\text { акустичні співи практикують у } \\
\text { невеликих кабінетах }\end{array}$ & $\begin{array}{l}\text { гучний, посилений спів у } \\
\text { конкуренції з гучністю } \\
\text { підсилених інструментів, } \\
\text { поганий слуховий контроль, } \\
\text { пошкодження слуху }\end{array}$ \\
\hline
\end{tabular}


Відмінності між класичною та сучасною вокальною технікою в своєму дослідженні виокремлює і Г. Холлі.

Таблиця 3

Відмінні риси КВТ та СВТ (за Г. Холлі) [9, с. 35].

\begin{tabular}{|c|c|c|c|}
\hline \multirow{11}{*}{ 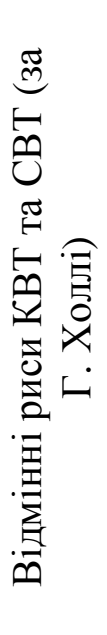 } & Елементи вокальної техніки & KBT & CBT \\
\hline & Вимова голосних & Округлена & Широка \\
\hline & Повітряний тиск & Великий & Менший ніж класичний \\
\hline & Дихання & Діафрагмальне & Діафрагмальне та грудне \\
\hline & Вібрато & 3 початку звуку & Як ефект \\
\hline & $\begin{array}{l}\text { Домінуючиий голосовий } \\
\text { механізм (вокальне } \\
\text { виробництво) }\end{array}$ & M2 (у жінок) & M1 \\
\hline & Ритм & Незмінний & Вільний \\
\hline & Якість звуку & Дзвінка & Металева \\
\hline & Звукова проекція & Природна & Підсилена мікрофоном \\
\hline & Регістраційні переходи & Плавні & Неприхована регістрація \\
\hline & Тлумачення тексту & Композиторське & Співацьке (виконавське) \\
\hline
\end{tabular}

Своє розуміння відмінностей у між КВТ та СВТ в процесі розробки педагогічних підходів до опанування підлітками-співаками здоровою технікою в сучасних стилях Б. Кемпфер окреслив наступним чином:

Таблиця 4

Відмінні риси КВТ та СВТ (за Б. Кемпфер) [10, р. 33].

\begin{tabular}{|c|c|c|c|}
\hline \multirow{11}{*}{ 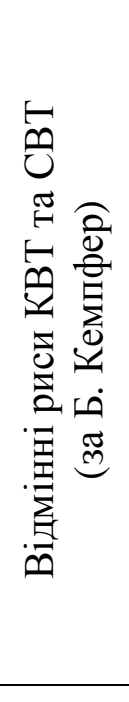 } & $\begin{array}{c}\text { Елементи вокальної } \\
\text { техніки }\end{array}$ & КВТ & CBT \\
\hline & Резонанс & Сбалансований & Різноманітний \\
\hline & Вібрато & Вібрато на опорі & Немає / як ефект \\
\hline & Вимова звуків & Пріоритет голосних & Пріоритет приголосних \\
\hline & Положення гортані & Низьке & Високе (як правило) \\
\hline & Вокальне виробництво & Тонкими складками & Товстими складками \\
\hline & Повітряний тиск & Великий & Менший \\
\hline & Щочні м'язи & Розслаблені & Активні \\
\hline & Положення піднебіння & $\begin{array}{l}\text { Високе / Не назальний } \\
\text { звук }\end{array}$ & $\begin{array}{l}\text { Може бути низьке / } \\
\text { Носовий призвук }\end{array}$ \\
\hline & Положення язику & $\begin{array}{l}\text { Розслаблений спереду / } \\
\text { низький }\end{array}$ & Високий \\
\hline & Домінантні м'язи & Крікоаритеноїдні & Тіроаритеноїдні \\
\hline
\end{tabular}

Спираючись на десрініції членів ААВП, К. Чандлера, Г. Холлі та Б. Кемпфера ми виокремили загальні відмінності СВТ від КВТ, а саме:

- розширення меж акустичних характеристик (акустична енергія; обертони; фрормантні зони; якість звуку; вібрато);

- більш чітко-визначена природність фрізіологічних процесів (придихання, 
як вид голосоведення; атака; домінуючиий голосовий механізм; співочий тон; діапазон; регістраційні переходи), які супроводжують некласичний спів;

- інтуітивність, неофіційність та неформальність виконавських дій (вимова тексту; візуалізація; місце виконання; багатоголосся; теоретичні знання);

- опора на загально-людські та етнічні традиції (інтонування; прикраси; імпровізація; вокальні ефекти);

- протилежності СВТ класичній техніці (постава; повітряний тиск; положення гортані; вокальне виробництво; положення язику; домінантні м'язи; дикція та вимова звуків; ритм; звукова проекція; посилення);

- індивідуальний творчий підхід до співу (візуалізація, вокальні ефекти, тлумачення тексту) тощо.

Аналіз інтерв'ю Н. Вудруфрфа (N. Woodruff) з Ж. ЛоВетрі дає можливість додати її основні принципи голосової функції в СВТ, такі як: сильна вирівняна постава, яка полегшує глибокий та легкий вдих та видих; розмовна позиція; відокремлення, трансформація та комбінування грудного та головного регістрів; зміна голосового виробництва та якості голосу для кожного стилю; неспотворені голосні; чітка вимова [11].

Інтонаційні та метро-ритмічні особливості сучасної вокальної техніки розглядаються у статті автора, присвяченій особливостям музичної мови сучасного естрадного вокалу [3].

Наочно складові КВТ та СВТ відображено на малюнку 1.

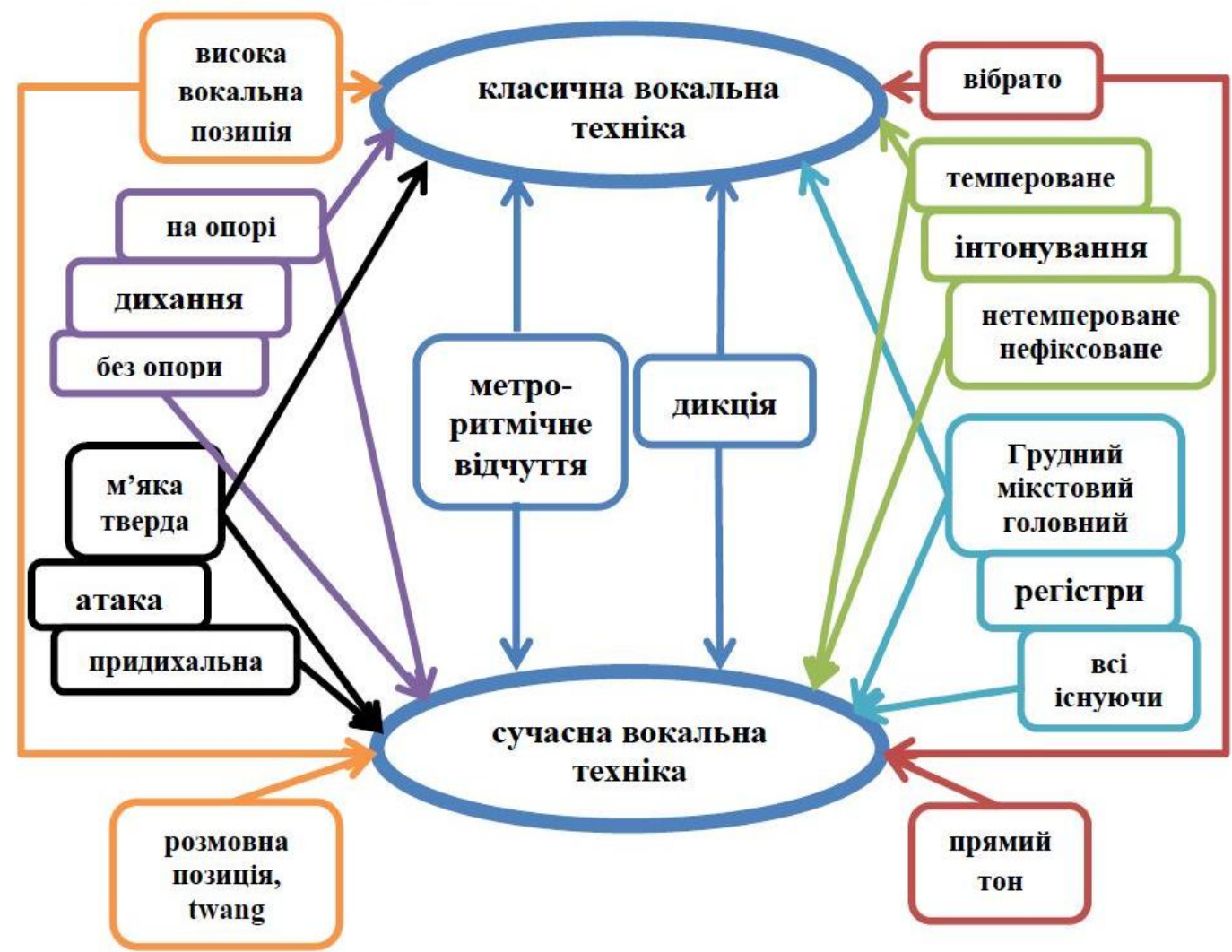

Малюнок 1. Складові КВТ та СВТ 
Висновки. Спираючись на вищевикладене та наш актуальний досвід зроблено висновок, що єдиними в СВТ та КВТ $є$ наявність чіткої дикції та метро-ритмічного відчуття, хоча в сучасній естрадній, і особливо в джазовій, музиці метро-ритм набагато складніший ніж в традиційній академічній музиці і потребує особливої уваги та додаткових зусиль до його опанування. Але, його основою $є$ загальна для усіх жанрів та стилів музики метрична пульсація. Що стосується інших елементів традиційної академічної вокальної техніки, а саме, дихання на опорі, висока вокальна позиція, темпероване інтонування, використання м'якої й твердої атаки звуку, грудного, мікстового та головного регістрів, вібрато, артистизм, які притаманні традиційній вокальній техніці, широко використовуються і у сучасному вокалі. В той же час, в естрадному вокальному виконавстві використовуються і неприпустимі з точки зору академічної традиції елементи (безопорне дихання, розмовна позиція та twang, нетемпероване та нефріксоване інтонування, всі існуючи регістри та різні види їх поєднання, прямий тон).

Перспектива подальшого дослідження полягає в тому, що в процесі роботи з естрадними вокалістами будь-якого рівня, і перш за все в мистецьких школах, необхідно буде впроваджувати вищезазначені особливості СВТ, що детермінуватиме переформатування і доповнення існуючої методики навчання естрадному співу та актуалізуватиме необхідність моделі фрормування сучасного естрадного вокально-виконавського тезаурусу учнів старших класів мистецьких шкіл.

\section{Використана література:}

1. Бойко О. Українська масова музика: етапи розвитку, національні особливості : дис. ... канд. мистецтвознавства: 17.00.03 / ІМФЕ ім. М. Т. Рильського НАН України. К., 2017. 215 с.

2. Данилова А. Своеобразие интерпретации категории “традиция” в эстетической теории и практике постмодернизма (на материале творчества Э. Денисова) : дис. ... канд. филос. наук : 09.00.04 / Краснодар, КГИК, 2009. 156 с.

3. Кулага Т. Основные особенности музыкального языка современного эстрадного вокала : матер. Всеукр. наук. інтерн.-конф. Вітчизняна наука на зламі епох: проблеми та перспективи розвитку, 17 жовт. 2019. Вип. 54. Переяслав-Хмельницький : ПХДПУ, 2019. 314 с.

4. Лобанова М. Музыкальный стиль и жанр: история и современность. Москва : Сов. композитор, 1990. 312 c.

5. Сегеда Н. Етнопедагогічні максими музично-педагогічної спадщини IX-XX ст. у контексті етнокультурологічного підходу. Проблеми сучасної педагогічної освіти. Сер.: Педагогіка $i$ психологія, 2014. Вип. 45., Ч. 3. Ялта: РВВ КГУ. С. 202-210.

6. Addison A., Bonazzi E., Christiansen L., Craig P. \& Others.In Support Of Contemporary Commercial Music (Nonclassical) Voice Pedagogy. Journal of Singing, 2008. Vol. 65, № 1. P. 7-10.

7. Chandler K. Teaching Popular Music Styles. Teaching Singing in the 21st Century, 2014. P. 35-51.

8. Henrich N., Roubeau B, Castellengo M. On the use of electroglottography for characterisation of the laryngeal mechanisms. Proceedings of the Stockholm Music Acoustics Conference, August 6-9, 2003 (SMAC 03), Stockholm, Sweden, 2003. Vol. 2. P. 455-458.

9. Holley G. From Classical to Music Theatre: A Vocalist's Experience. Doctor's Thesis. Queensland Conservatorium. South Brisbane, 2016. $110 \mathrm{c}$.

10. Kempfer B. Contemporary Commercial Music Pedagogy: Selective Exercises for Developing Healthy Technique in Adolescent Singers. Master's Thesis. The University of Wisconsin. Milwaukee, 2014. $109 \mathrm{p}$.

11. Woodruff N. Contemporary Commercial Voice Pedagogy Applied to the Choral Ensemble: An Interview with Jeannette LoVetri. Choral Journal, 2011. Vol. 52 № 5. P. 39-53. 


\section{References:}

[1] Boiko, O. (2017). Ukrainian mass music: stages of development, national features. PhD. IMFE im. M. T. Rylskoho NAN Ukrainy. [in Ukraine]

[2] Danilova, A. (2009). The peculiarity of the interpretation of the category "tradition" in the aesthetic theory and practice of postmodernism (based on the material of creativity of E. Denisov). $\mathrm{PhD}$. Krasnodarskii Gosudarstvennii Institut Culturi. [in Russia]

[3] Kulaha, T. (2019). The main features of the musical language of contemporary pop vocal. In: Domestic science at the breaking of epochs: problems and prospects of development, 54. [online]. PereyaslavKhmelnitsky Gosudarstvennii Pedagogicheskii Universitet im. Grigoriia Skovorody, 113-116. Available at: https://confscience.webnode.com.ua/ [Accessed 11 Nov. 2019]. [in Russia]

[4] Lobanova, M. (1990). Musical style and genre: history and modernity. Moscow, Sovetskii compositor. [in Russia]

[5] Seheda, N. (2014). Ethno-pedagogical maxims of the musical-pedagogical heritage of IX-XX centuries in the context of an ethnocultural approach. Problems of modern pedagogical education. Series: Pedagogy and Psychology, 45 (3), pp. 202-210. [in Ukraine]

[6] Addison, A., Bonazzi, E., Christiansen, L., Craig, P. \& Others. (2008). In Support Of Contemporary Commercial Music (Nonclassical) Voice Pedagogy. Journal of Singing, 65 (1), pp. 7-10. [in English]

[7] Chandler, K. (2014). Teaching Popular Music Styles. Teaching Singing in the 21 st Century, pp. 35-51. [in English]

[8] Henrich, N., Roubeau, B, Castellengo, M. (2003). On the use of electroglottography for characterisation of the laryngeal mechanisms. Proceedings of the Stockholm Music Acoustics Conference, August 6-9, 2003 (SMAC 03), Stockholm, Sweden, 2, pp. 455-458. [in English]

[9] Holley, G. (2016). From Classical to Music Theatre: A Vocalist's Experience. Doctor. Queensland Conservatorium. South Brisbane. [in English]

[10] Kempfer, B. (2014). Contemporary Commercial Music Pedagogy: Selective Exercises for Developing Healthy Technique in Adolescent Singers. Master. The University of Wisconsin. [in English]

[11] Woodruff, N. (2011). Contemporary Commercial Voice Pedagogy Applied to the Choral Ensemble: An Interview with Jeannette LoVetri. Choral Journal, 52 (5), pp. 39-53. [in English]

КУЛАГА Т. А. Научно-методическая рефлексия классической и современной вокальной техники в контексте проблемы культуросоответствия вокальной педагогіки.

В статье подчеркнуто общую тендениию современного неклассического пения, которая отражкается в возвращении $\kappa$ природнылм возможностей человеческого голоса. Предоставлена систематизированная сравнительная характеристика основных черт классической и современной вокальных техник с точки зрения звукоизвлечения; типичных акустических характеристик голоса; техники; музыкальности и интерпретации. Приведены сравнения некоторых позиций, которые челесообразно учитывать в прочессе педагогического взаимодействия с певиами-подростками по овладению вокальной техникой в современных стилях. Определены различия между современной неклассической и традиционной западно-европейской вокальныли техниками с позиций принципа культуросообразности, а именно: расширение грании акустических характеристик голоса; более четкоопределенная естественность физиологических процессов, которые сопровождают неклассический пение; интуитивнисть, неофициальность и неформальность исполнительских действий современного эстрадного вокалиста; опора на разнообразные этнические традиции; индивидуальный творческий подход к интерпретачии и представления современного вокального произведения. Определены противоположные позиции классической и современной вокальной техниками, такие как осанка, воздушное давление, положение гортани и языка, звукообразование, доминантные мыпшы, звуковая проекиия, произношение звуков. Предоставлено ссылки на информаиию относительно интонационных и метро-ритмических особенностей музыкального языка современного эстрадного вокала. Отмечена необходимость переосмысления вокальной педагогики в соответствии с результатами современных исследований зарубежных ученых и учета полученных результатов в прочессе работы с эстрадныли вокалистами музыкальньхх школ.

Ключевые слова: культуросоответствие, ресемантизация, вокальная техника, эстрадный вокал, неклассическая вокальная педагогика, внешкольное образование. 
KULAHA T.O. Scientific and methodical reflection of classical and contemporary vocal techniques in the context of the problem of cultural-conformity of vocal pedagogy.

The article emphasizes the general trend of contemporary non-classical singing, which is reflected in the return to the natural possibilities of the human voice. A systematic comparative description of the main features of classical and contemporary vocal techniques from the point of view of production of sound, of typical acoustic characteristics of the voice, technics, musicality and interpretation is provided. Comparisons of some positions that are advisable to take into account in the process of pedagogical interaction with teenage singers on mastering the vocal technique in contemporary styles are given. The differences between contemporary non-classical and traditional Western European vocal techniques from the standpoint of the principle of cultural-conformity are defined. This is an expanding the boundaries of the acoustic characteristics of the voice; a more clearly defined naturalness of the physiological processes that accompany non-classical singing; intuitiveness, informality and informality of the performing actions of a contemporary pop vocalist; reliance on diverse ethnic traditions; individual creative approach to interpretation and presentation of a contemporary vocal composition. Opposing positions between classical and contemporary vocal techniques (posture, air pressure, position of the larynx and tongue, sound formation, dominant muscles, sound projection, pronunciation of sounds) are determined. Link to information on the intonational and metro-rhythmic features of the musical language of contemporary pop vocal are provided. The necessity of rethinking vocal pedagogy in accordance with the results of modern research by foreign scientists and taking the obtained results in the process of working with pop vocalists of art schools is noted.

Keywords: cultural-conformity, resemantization, vocal technique, pop vocal, non-classical vocal pedagogy, non-formal education.

DOI: https://doi.org/10.31392/NZ-npu-144.2019.14

УДК 003.08:372.881.111.1]-057.875.001.85

Лазаренко Л. М.

\section{ОСОБЛИВОСТІ КОНТРОЛЮ ЗНАНЬ, ВМІНЬ ТА НАВИЧОК ПРОФЕСІЙНО ОРІЄНТОВАНОГО ПИСЬМА АНГЛІЙСЬКОЮ МОВОЮ СТУДЕНТІВ ЕКОНОМІЧНИХ СПЕЦІАЛЬНОСТЕЙ}

Сформовані знання, вміння та навички професійно орієнтованого письма англійською мовою у майбутніх економістів сприяють високій конкурентоспроможності циих фахівців як в Украӥні, так $i$ за кордоном. Визначено, що тільки систематичне проведення контролю будь-якого виду діяльності, зокрема письма, сприяє підвищенню успішності з дисиипліни внаслідок самокорекиії та корекиї з боку викладача. Існують численні дослідження особливостей проведення контролю саме компоненту письма, проте в даній статті автором було структуровано типи завдань відповідно до різних напрямків письма. Автором зазначено дві стадї вивчення іноземної мови у закладі вищої освіти: опанування базових знань, вмінь та навичок на рівні не ниюче B1, і також вивчення власне професійного блоку. Показано основні 3 напрямки письмових завдань для майбутніх економістів англійською мовою: заповнення економічної документації, реферування та анотування, а також написання власних наукових статей за фахом англійською мовою. Автором визначено, що написання завдань з контролю знань, вмінь та навичок професійного письма англійською мовою визначає рівень орфографічних, лексичних, граматичних та стилістичних знань, вмінь та навичок студентів. Автором підкреслено, щуо опанування знань, вмінь та навичок професійного письма студентами-економістами вимагає сформованості трьох основних компетентностей: когнітивної, метакогнітивної та стратегічної. У статті автором наведені приклади завдань для контролю кожного зі зазначених блоків, описано інструкцію до кожного з них. Показано, щуо систематичне проведення контролю письма сприяє підвищенню успішності студентів. Автор вважсає перспективним проведення подальшого емпіричного дослідження порівняння навчання та контролю знань, вмінь та навичок письма студентів нефілологічних спеціальностей (економістів) та письма студентів філологічних спеціальностей.

Ключові слова: контроль, письмо, економісти, англійська мова. 